\title{
Mineral dynamics in forages of the Northern Great Plains
}

\author{
E. E. GRINGS, M. R. HAFERKAMP, R. K. HEITSCHMIDT AND M. G. KARL
}

Authors are research animal scientist, rangeland scientist, supervisony rangeland scientist, and post-doctoral rangeland scientist at USDA-ARS, Fort Keogh Livestock and Range Research Laboratory, Rte. 1, Box 2021, Miles City, Mont. 59301.

\begin{abstract}
Mineral concentrations of range grasses are often below that required by grazing livestock. Limited information is available on forage mineral concentrations for the Northern Great Plains and there is little data on factors influencing concentrations of forage minerals throughout the year. Therefore, a study was conducted to evaluate spacial and temporal variations in mineral concentrations of major forage species in the Northern Great Plains. Herbage was sampled from 4 replicates on each of 2 soils in July, August, and September 1991, April, June, July, August, and September 1992, and April 1993. Herbage was sorted by species grouping and by live and dead tissue classes. Analyses on herbage included $\mathrm{Ca}, \mathrm{P}, \mathrm{Mg}, \mathrm{K}, \mathrm{Na}, \mathrm{Zn}, \mathrm{Cu}, \mathrm{Mn}$, and $\mathrm{Mo}$. For western wheatgrass [Pascopyrum smithii (Rydb.) Love] and annual bromes [Bromus spp.], $\mathrm{Zn}$ and all macrominerals except $\mathrm{Na}$ were greater in live than in dead tissue. Live tissues of all other species groupings contained greater amounts of $\mathbf{P}$ and $K$ than did dead tissue. Live tissue $\mathbf{M g}$ concentrations were greater than dead tissue concentrations for other cool-season and warmseason grasses. Manganese concentrations were greater in live than dead annual brome tissues, while $\mathrm{Cu}$ was greater in dead than live tissue. Dead sedge tissue contained greater concentrations of $\mathrm{Ca}$ than live tissue. Soil type affected several nutrients but this was partially related to soil effects upon composition of species groupings and live:dead ratios. Minerals most likely to be found in quantities less than required for animal production were $\mathrm{P}, \mathrm{Na}, \mathrm{K}, \mathrm{Zn}$, and $\mathrm{Cu}$.
\end{abstract}

Key Words: forage quality, grasslands, trace elements, nutritive value

Devising effective nutritional management strategies for grazing livestock requires an understanding of the dynamics of a broad range of forage nutrients. Although protein and energy are 2 nutrients commonly deficient for at least part of the year (Adams and Short 1988), potential mineral deficiencies are also often reported (Rauzi et al. 1969, Murray et al. 1978, Grings

\footnotetext{
This paper is a contribution from the USDA-ARS and the Montana Agricultural Experiment Station (J-3015).

Mention of any trade name or any proprietary product does not constitute a guarantee or warranty by the authors or USDA-ARS nor does it imply the approval of these products to the exclusion of others.

Manuscript accepted 3 June 1995.
}

1979, Hinnant and Kothmann 1982, Greene et al. 1987, Pinchak et al. 1989). Moreover, mineral concentrations in herbage tend to vary with soil fertility, plant species, stage of plant maturity, availability of water, and tissue age (Fleming 1973, Greene et al. 1987).

Limited information is available currently on concentrations of minerals in forages of the Northern Great Plains. Marsh et al. (1959) monitored P concentrations in selected forage species in eastern Montana and found them to be below recommended levels for beef cattle (NRC 1984). When the mineral composition of 4 range grasses growing in Rosebud County, Montana was examined by Munshower and Neuman (1978), $\mathrm{Zn}$ and $\mathrm{Cu}$ concentrations were found to be below recommended levels for cattle during much of the year. Karn and Hofmann (1990) found $\mathrm{Cu}$ concentrations of forage selected by grazing cattle on a North Dakota study site to be below recommended levels. The $\mathrm{Cu}$ status of cattle grazing the area, as measured by serum and liver $\mathrm{Cu}$ levels, was less than desired for optimal beef cattle production. Further definition of the concentrations of minerals in important forages in the Northern Great Plains appears warranted. Pinchak et al. (1989) suggested that biologically realistic bounds for mineral status of livestock diets could be determined through evaluation of live versus whole plant concentrations of minerals. Selection of only live tissue would provide a maximum mineral concentration while consumption of whole plants would provide a minimal level of mineral. The objective of this study was to evaluate spacial and temporal variation in mineral concentrations in major forages growing in the Northern Great Plains.

\section{Materials and Methods}

Research was conducted at the Fort Keogh Livestock and Range Research Laboratory, Miles City, Mont. $\left(46^{\circ} 22^{\prime} \mathrm{N}, 105^{\circ} 5^{\prime}\right.$ W). Long term annual precipitation averages $338 \mathrm{~mm}$ of which about $60 \%$ is received during a 150-day mid-April to midSeptember growing season. Average daily temperatures range from a low of $-10^{\circ} \mathrm{C}$ in January to a high of $24^{\circ} \mathrm{C}$ in July.

Eight $30 \times 30-\mathrm{m}$ replicate plots were located in pastures grazed at a moderate stocking rate with mature cows during the fall and winter. Four replicate plots were located on each of 2 soils: Eapa loam (Aridic Argiboroll, fine-loamy, mixed), a deep, welldrained, silty loam soil of moderate permeability; and Sonnet silty clay (Typic Eutroboroll, fine montmorillonitic), a rather 
impermeable clay loam with an impervious B horizon claypan 5 to $20 \mathrm{~cm}$ below the soil surface. Dominant plant species were western wheatgrass [Pascopyrum smithii (Rydb.) Love], a perennial cool-season midgrass and 2 annual grasses, Japanese brome [Bromus japonicus Thunb.], and downy brome [Bromus tectorum L.]. Other important perennial grasses were needle-and-thread [Stipa comata Trin. and Rupr.], Sandberg's bluegrass [Poa secun$d a$ Presl.], and blue grama [Bouteloua gracilis (H.B.K.) Lag. ex Griffiths]. Threadleaf sedge [Carex filifolia Nutt.] was also common. Dominant forbs and half-shrubs were western salsify [Tragopogon dubius Scop.], fringed sagewort [Artemisia frigida Willd.], and common dandelion [Taraxacum officinale Weber]. Estimated range condition was good on the Eapa loam soil and fair on the Sonnet silty clay soil (SCS 1983).

Standing crop inside 10 randomly located $0.25-\mathrm{m}^{2}$ quadrats per replication was harvested by species at ground level on 9 dates from July 1991 to April 1993. Herbage was bagged by species group, dried at $60^{\circ} \mathrm{C}$ for 48 hours, and weighed. Herbage from the 10 quadrats within each replicate was collated by species. Live and dead material were then hand separated, weighed to estimate live:dead ratios and ground to pass a $1-\mathrm{mm}$ screen for chemical analysis. Samples were analyzed for $\mathrm{Ca}, \mathrm{P}, \mathrm{Mg}, \mathrm{K}, \mathrm{Na}, \mathrm{Zn}, \mathrm{Cu}$, $\mathrm{Mn}$, and Mo by inductively coupled plasma atomic emission spectroscopy at Northeast DHIA, Ithaca, N.Y. (Sirois et al. 1994). Due to limited biomass, several species were further combined mathematically into species groups after chemical analyses. This included other cool-season grasses which consisted of needleand-thread, Sandberg's bluegrass, green needlegrass [Stipa viridula Trin.], and other cool-season grasses found in minor quantities. The annual brome group consisted of downy and Japanese bromes. The warm-season grass group was comprised of blue grama and buffalograss [Buchloe dactyloides (Nutt.) Engelm]. Sedges were primarily threadleaf sedge. Hereafter, all individual species and species groups will be referred to as species groups.

Data were analyzed using the general linear models procedure of SAS (1985) and are presented as least squares means. Analyses were conducted using 2 models for each species grouping. The first included nutrient concentrations by tissue class and the second used whole plant mineral values. Whole plant values were obtained mathematically from the live and dead tissue data. Western wheatgrass was the only species growing on both soils for which live and dead material was collected on every sample date. Thus, it was the only species used to test soil $X$ tissue class interaction effects. The model for western wheatgrass included main effects of soil type, date, and tissue class plus associated 2and 3-way interactions. Soil effects were tested using the replicate within soil mean square as the error term. Tissue class and tissue class $X$ soil effects were tested using the replicate within soil $X$ tissue class mean square as the error term. Other interactions were tested with the residual mean square as the error term. Data for other species groups were analyzed with a model that included tissue class, date, and their interaction. For these analyses, the effect of tissue class was tested using the replicate $X$ tissue class mean square as the error term. Some dates were not included in the analyses because only $I$ tissue class was present on a date. Whole plants of western wheatgrass, other cool-season grasses, and annual bromes were evaluated with a model that included soil, date, and the soil $x$ date interaction. Soil effects were tested using the replicate within soil mean square as the error term and the residual error was used to test other effects.
Sedges, warm-season grasses, and forbs were not found frequently enough on both soils to allow a meaningful analysis of soil effects; therefore, whole plant mineral concentrations for these species groupings were analyzed with a model that contained date only. The dates used for analyses varied by species group. Because of analytical difficulties, there were no $\mathrm{Cu}$ values for August or September 1991, and these dates were deleted from the analysis for $\mathrm{Cu}$. Differences among means were considered significant at $P<0.05$. Trends towards significance were considered for $0.10<P>0.05$.

\section{Results and Discussion}

\section{Growing Conditions and Stages of Maturity}

Precipitation was well above normal in 1991 and near normal in 1992 (Fig. 1). Temperatures during late winter and early spring 1991 were well above normal $\left(\approx+4^{\circ} \mathrm{C}\right)$ whereas temperatures during late spring, summer, and fall were near normal (NOAA 1992). Temperatures during the winter of 1991-92 were again well above normal $\left(\approx+6^{\circ} \mathrm{C}\right)$ with temperatures thereafter near to slightly below normal. Temperature and precipitation were near normal in the winter of 1992-93 but April 1993 precipitation was slightly above normal. As a result of these climatic conditions, 1991 was an exceptional growing year with 1992 considered an average to slightly above average year and the spring of 1993 was also an average to slightly above average growing period.

Western wheatgrass plants were mostly vegetative throughout the year. Those few plants that produced inflorescences were in the hard dough stage by July of both years. Other cool-season grasses on the silty clay soil (primarily bluegrasses) produced inflorescences by April 1992 while other cool-season grasses growing on loam soil (primarily needle-and-thread) were still vegetative. By June 1992, other cool-season grasses on silty clay soil were in the hard dough stage, while those on loam soil were in anthesis. Phenology for this species grouping was similar between soils on other dates (seed shatter). Warm-season grasses were mostly vegetative but some inflorescences were present in July through September. Brome seedlings were actively growing in June 1992, September 1992, and April 1993. In June 1992,

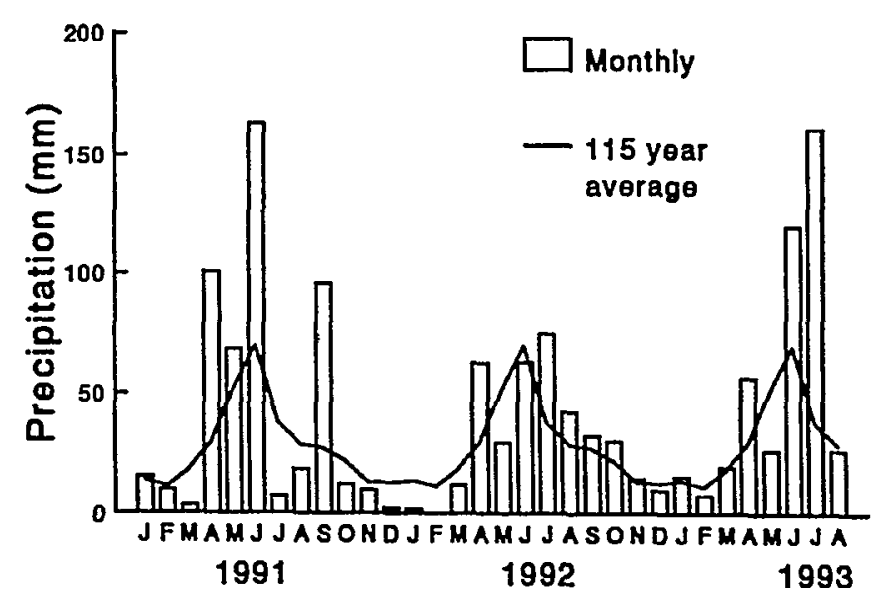

Fig. 1. Precipitation during the sampling period compared to a 115 year average. 
seed of downy brome was shattering its seed while Japanese brome was in soft dough. The bromes were at comparable stages of maturity on other dates.

\section{Macronutrients \\ Calcium}

Lactating beef cows require 0.27 to $0.58 \% \mathrm{Ca}$, depending on body size and milking ability (NRC 1984). Average whole plant concentrations of warm-season grasses $(0.32 \%)$, sedges $(0.42 \%)$, and forbs $(0.89 \%)$ met this requirement while western wheatgrass (Fig. 2) and annual bromes (Table 1) fell within this range only for some soil type-date combinations. Calcium concentrations of other cool-season grasses averaged $0.20 \%$ and were never within the requirement range.

Whole plant $\mathrm{Ca}$ concentrations of western wheatgrass (Fig. 2), annual bromes, and forbs (Table 1) varied over time, with the pattern of change varying among species. Lowest concentrations were observed in August 1991 for forbs and April and June for western wheatgrass. Concentrations of $\mathrm{Ca}$ in forbs were quite high throughout the sampling periods, often being 3 to 4 times the concentrations found in grasses and sedges. Whole plant $\mathrm{Ca}$ concentrations of annual bromes were greatest in April 1993 and exhibited a date $X$ soil interaction due to greater Ca concentrations in bromes growing on loam soil in April 1992 and 1993 than bromes growing on the silty clay soil.

On average, live tissue of western wheatgrass and annual bromes contained more $\mathrm{Ca}$ than did dead tissue of these species (Table 2). Patterns of change in Ca concentrations over time differed by tissue class (tissue class $X$ date interaction) in these 2 species. Live tissue $\mathrm{Ca}$ concentrations of western wheatgrass increased between July and August 1991, and from June through August of 1992. Live tissue $\mathrm{Ca}$ concentrations were greater than concentrations in dead tissue from June through September of 1992 (Fig. 2). Although Ca concentrations in annual brome tis-

Table 1. Least squares means of whole plant mineral concentrations (dry matter basis) by species groupings and soil type where appropriate for 9 dates from July 1991 to April 1993.

\begin{tabular}{|c|c|c|c|c|c|c|c|c|c|c|c|}
\hline \multirow{2}{*}{$\begin{array}{l}\text { Species } \\
\text { Group }\end{array}$} & \multirow[b]{2}{*}{ Mineral } & \multicolumn{7}{|c|}{ Date } & \multirow[b]{2}{*}{$\begin{array}{c}\text { 19-Sep. } \\
1992\end{array}$} & \multirow[b]{2}{*}{$\begin{array}{c}\text { 27-Apr. } \\
1993\end{array}$} & \multirow[b]{2}{*}{ S.E.M. } \\
\hline & & $\begin{array}{c}\text { 10-Jul. } \\
1991\end{array}$ & $\begin{array}{c}\text { 14-Aug. } \\
1991\end{array}$ & $\begin{array}{c}\text { 14-Sep. } \\
1991\end{array}$ & $\begin{array}{c}\text { 25-Apr. } \\
1992\end{array}$ & $\begin{array}{c}\text { 02-Jun. } \\
1992\end{array}$ & $\begin{array}{c}\text { 16-Jul. } \\
1992\end{array}$ & $\begin{array}{c}\text { 12-Aug. } \\
1992\end{array}$ & & & \\
\hline \multicolumn{12}{|c|}{ Westem wheatgrass } \\
\hline & $\mathrm{Mn}^{1}, \mathrm{ppm}$ & $39^{d}$ & $39^{d}$ & $51^{\mathrm{b}}$ & $67^{\mathrm{a}}$ & $42^{\text {cd }}$ & $42^{\mathrm{cd}}$ & $45^{\mathrm{bcd}}$ & $50^{\mathrm{b}}$ & $49^{\text {be }}$ & 1.0 \\
\hline \multicolumn{12}{|c|}{ Other cool-season grasses } \\
\hline Silty clay ${ }^{2}$ & $\mathrm{P}, \%$ & $\mathrm{na}^{3}$ & $0.09^{\mathrm{b}}$ & $0.07^{\mathrm{b}}$ & $0.32 \mathrm{a}$ & na & $0.07_{\mathrm{A}}^{\mathrm{b}}$ & $0.05^{\mathrm{b}}$ & na & na & 0.007 \\
\hline Loam & & па & $0.13^{a b}$ & $0.08^{b}$ & $0.10_{\mathrm{B}}^{\mathrm{ab}}$ & na & $0.16_{\mathrm{B}}^{\mathrm{a}}$ & $0.13^{a b}$ & na & na & \\
\hline Silty clay $^{2}$ & $\mathrm{Mg}, \%$ & na & $0.10^{b}$ & $0.08^{b}$ & $0.19_{A}^{a}$ & na & $0.08^{b}$ & $0.08^{\mathrm{b}}$ & na & na & 0.005 \\
\hline Loam & & na & $0.12^{a}$ & $0.10^{3}$ & $0.05_{B}^{b}$ & na & $0.11^{a}$ & $0.10^{\mathrm{a}}$ & na & na & \\
\hline Silty clay ${ }^{2}$ & $\mathrm{~K}^{1}, \%$ & na & $0.49^{\mathrm{b}}$ & $0.38^{\mathrm{b}}$ & $1.90_{A}^{\sharp 4}$ & na & $0.38_{\mathrm{A}}^{b}$ & $0.36^{\mathrm{b}}$ & na & na & 0.039 \\
\hline Loam & & na & $0.90^{2}$ & $0.47^{\mathrm{b}}$ & $0.59_{\mathrm{B}}^{\mathrm{ab}}$ & na & $0.83_{B}^{a b}$ & $0.80^{\mathrm{ab}}$ & na & ла & \\
\hline Silty clay ${ }^{2}$ & $\mathrm{Na}^{\mathrm{l}}, \mathrm{F}$ & na & $0.007_{\mathrm{A}}^{\mathrm{c}}$ & $0.004^{d}$ & $0.022_{\mathrm{A}}^{\mathrm{a}}$ & na & $0.002^{d}$ & $0.010_{\mathrm{A}}^{\mathrm{b}}$ & na & na & 0.0001 \\
\hline Loam & & na & $0.003_{B}$ & 0.002 & $0.002_{\mathrm{B}}$ & na & 0.002 & $0.002_{\mathrm{B}}$ & па & na & \\
\hline \multicolumn{12}{|c|}{ Warm-season grasses } \\
\hline & $\mathrm{P}^{1}, \%$ & na & $0.18^{a b}$ & $0.11^{\mathrm{c}}$ & na & $0.20^{a}$ & $0.20^{\mathrm{a}}$ & $0.16^{\mathrm{ab}}$ & $0.12^{\mathrm{bc}}$ & $0.08^{\mathrm{C}}$ & 0.006 \\
\hline & $\mathrm{K}^{1}, \%$ & na & $0.59^{\mathrm{abc}}$ & $0.41^{\mathrm{c}}$ & na & $1.16^{\mathrm{a}}$ & $0.67^{\text {abc }}$ & $0.83^{\mathrm{ab}}$ & $0.51^{b c}$ & $0.24^{c}$ & 0.005 \\
\hline & $\mathrm{Zn}^{1}, \mathrm{ppm}$ & na & $21^{b}$ & $33^{b}$ & na & $21^{b}$ & $59^{a}$ & $17^{\mathrm{b}}$ & $16^{b}$ & $15^{b}$ & 0.8 \\
\hline \multicolumn{12}{|c|}{ Annual bromes } \\
\hline Silty clay $^{2}$ & $\mathrm{Ca}^{1}, \%$ & $0.16^{c}$ & $0.17^{\mathrm{bc}}$ & $0.21^{\mathrm{b}}$ & $0.23_{A}^{b}$ & $0.21^{\mathrm{b}}$ & $0.20^{\mathrm{be}}$ & $0.19^{b c}$ & $0.24^{a b}$ & $0.29_{\mathrm{A}}^{\mathrm{a}}$ & 0.004 \\
\hline \multirow[t]{6}{*}{ Loam } & & $0.22^{\mathrm{c}}$ & $0.25^{\mathfrak{C}}$ & $0.23^{\mathrm{c}}$ & $0.35_{\mathrm{B}}^{\mathrm{b}}$ & $0.21^{\mathrm{e}}$ & $0.27^{\mathfrak{c}}$ & $0.27^{\mathrm{c}}$ & $0.26^{\mathrm{C}}$ & $0.43_{\mathrm{B}}^{\mathrm{a}}$ & \\
\hline & $\mathrm{P}^{1}, \%$ & $0.16^{c}$ & $0.09^{d}$ & $0.08^{d}$ & $0.21^{b}$ & $0.21^{b}$ & $0.10^{\mathrm{d}}$ & $0.09^{\mathrm{d}}$ & $0.10^{\mathrm{d}}$ & $0.28^{3}$ & 0.004 \\
\hline & $\mathrm{Mg}^{1}, \%$ & $0.11^{\mathrm{c}}$ & $0.10^{\text {ed }}$ & $0.09^{d}$ & $0.15^{\mathrm{b}}$ & $0.15^{\mathrm{b}}$ & $0.11^{\mathrm{cd}}$ & $0.10^{\mathrm{cd}}$ & $0.11^{\text {cd }}$ & $0.18^{a}$ & 0.002 \\
\hline & $\mathrm{K}^{1}, \%$ & $0.48^{d}$ & $0.25^{\mathrm{cd}}$ & $0.21^{d}$ & $1.48^{\mathrm{b}}$ & $0.93^{c}$ & $0.21^{\mathrm{d}}$ & $0.17^{d}$ & $0.52^{\mathrm{cd}}$ & $2.16^{\mathrm{a}}$ & 0.031 \\
\hline & $\mathrm{Cu}^{1}, \mathrm{ppm}$ & $2^{b}$ & na & na & $4^{a}$ & $2^{b}$ & $2^{b}$ & $2^{b}$ & $3^{b}$ & $4^{a}$ & 0.1 \\
\hline & $\mathrm{Mn}^{1}, \mathrm{ppm}$ & $80^{b}$ & $86^{a b}$ & $65^{b}$ & $106^{\mathrm{a}}$ & $87^{\text {ab }}$ & $68^{b}$ & $68^{b}$ & $61^{b}$ & $93^{\mathrm{ab}}$ & 2.6 \\
\hline \multicolumn{12}{|l|}{ Sedges ${ }^{4}$} \\
\hline & $\mathrm{P}^{1}, \%$ & $0.12^{b}$ & $0.08^{b}$ & na & $0.19^{\mathrm{a}}$ & $0.13^{b}$ & na & $0.09^{b}$ & $0.11^{\mathrm{b}}$ & $0.18^{\mathrm{a}}$ & 0.005 \\
\hline & $\mathrm{Zn}^{1}, \mathrm{ppm}$ & $11^{d}$ & $34^{a}$ & na & $27^{a b}$ & $16^{\mathrm{cd}}$ & na & $25^{\mathrm{abc}}$ & $12^{\mathrm{d}}$ & $25^{b c}$ & 0.9 \\
\hline & $\mathrm{Cu}^{\prime}, \mathrm{ppm}$ & $1^{c}$ & na & na & $7^{b}$ & $4^{b c}$ & na & $24^{2}$ & $1^{\mathrm{c}}$ & $3^{b c}$ & 0.5 \\
\hline \multicolumn{12}{|l|}{ Forbs ${ }^{4}$} \\
\hline & $\mathrm{Ca}^{1}, \mathrm{~s}_{0}^{\circ}$ & $1.01^{\mathrm{a}}$ & $0.60^{\mathrm{b}}$ & $\mathrm{na}$ & $0.90^{\mathrm{a}}$ & $0.99^{\mathrm{a}}$ & na & $1.04^{2}$ & $0.92^{\mathrm{a}}$ & $0.82^{a}$ & 0.025 \\
\hline & $P^{1}, \%$ & $0.25^{a b}$ & $0.12^{\mathrm{b}}$ & па & $0.35^{\mathrm{a}}$ & $0.23^{a b}$ & na & $0.27^{\mathrm{a}}$ & $0.25^{\mathrm{a}}$ & $0.29^{a}$ & 0.016 \\
\hline & $K^{1}, \%$ & $2.02^{a b}$ & $1.32^{\mathrm{c}}$ & na & $3.72^{\mathrm{a}}$ & $3.56^{\mathrm{a}}$ & na & $1.76^{\mathrm{be}}$ & $2.98^{a b}$ & $2.67^{a b}$ & 0.144 \\
\hline
\end{tabular}

Means in rows with different superscripts differ by date $(\mathrm{P}<0.05)$.

${ }^{2}$ Results from the 2 soil types are listed separately whun significant soil by date interactions occurred. Soil type means within columns and elements with different subscripts differ $(\mathrm{P}<0.05)$.

Data not available for a given date.

Soil type was not included in the analysis for this species grouping. 

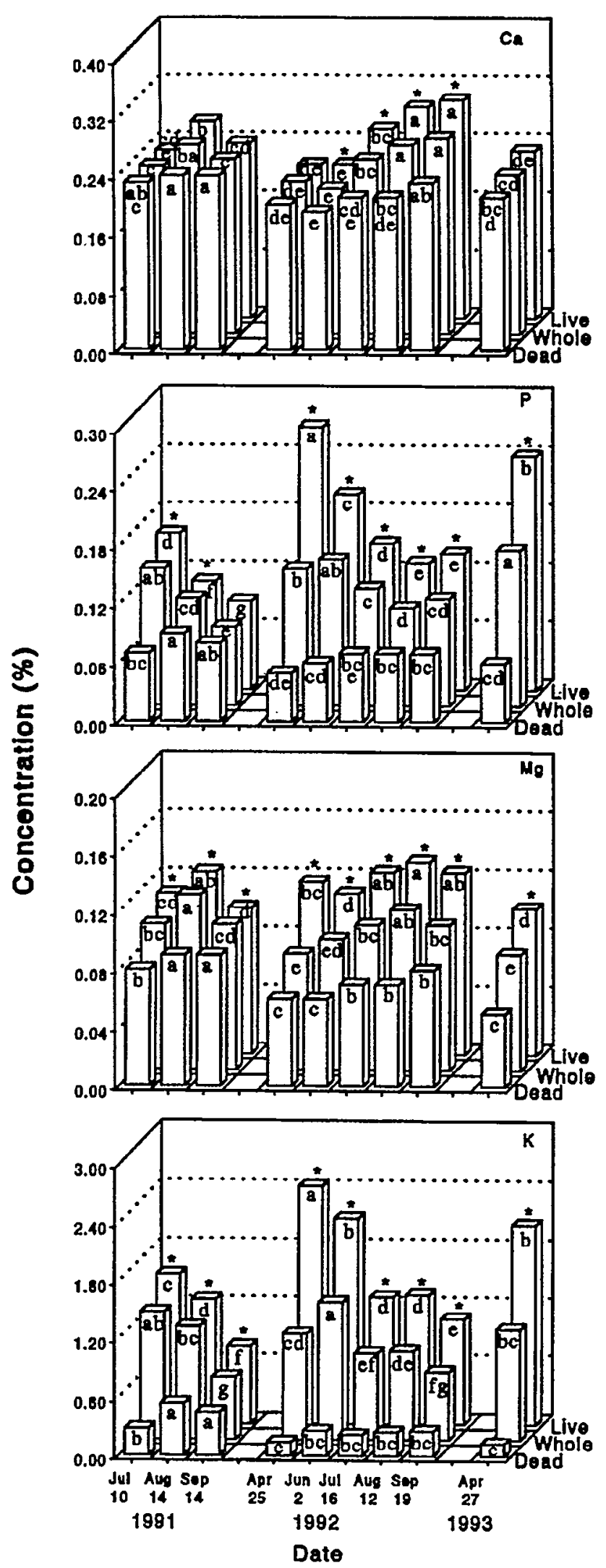

Fig. 2. Live, dead, and whole plant macromineral (Ca, P, Mg, K) concentrations ( $\%$ of dry matter) for western wheatgrass on 9 dates. Asterisks represent dates on which live and dead tissue mineral concentrations differ $(P<0.05)$. Mineral concentrations over dates within tissue class with different letters differ $(P<0.05)$. sues varied (data not shown), they did not follow consistent patterns in relation to growing season. In contrast to other species, dead tissue of sedges contained more $\mathrm{Ca}$ than did live tissue (Table 2).

\section{Phosphorus}

Forbs were the only whole plant species grouping that generally contained more than $0.22 \% \mathrm{P}$, the minimum requirement for a lactating beef cow (NRC, 1984). Forbs were below this requirement in August 1991, however. Phosphorus levels above $0.22 \%$ were also observed for whole plants of annual bromes in April 1993, and by other cool-season grasses on silty clay soils in April 1992.

Whole plant $P$ concentrations of all species groups except forbs (Fig. 2, Table 1) declined between the earlier and later parts of the growing season due primarily to decreases in live tissue $P$ as plants aged. Annual bromes grown on silty clay soil tended to have greater $P$ content $(0.16 \%)$ than when grown on the loam soil (0.13\%). In April 1992, P concentrations for other cool-season grasses were greatest in herbage from the silty clay soil while in July 1992, herbage from the loam soil contained greater $\mathrm{P}$ concentrations (Table 1).

Live and dead tissues differed in $\mathrm{P}$ content in all species groupings (Table 2). The pattern of change over time in all species groupings was similar to that shown for western wheatgrass in Figure 2. Phosphorus concentrations in dead tissue remained relatively constant and low while in live tissue P started high and then decreased as the growing season progressed and tissue aged. Live tissue $P$ was closely associated with peak plant growth. This is similar to the results of Greene et al. (1987) who found P concentrations in dead tissue were about $60 \%$ less than concentrations in live tissue. Although diet selection may play a major role in $P$ intake, $P$ supplementation may be necessary to meet NRC requirements. Beef cows with high milk production potential may benefit from $\mathrm{P}$ supplementation throughout the year and supplementation may benefit all cows beginning in June or early July. Our study did not address the variation in mineral content among plant parts (leaf vs. stem) which, through diet selection, may also affect dietary P concentrations. Karn (1992) did not observe a response to $P$ supplementation of Hereford and Hereford-cross cows grazing Northern Great Plains rangeland. However, in that study $\mathrm{P}$ was supplied in a free-choice mineral mixture which was poorly consumed.

\section{Magnesium}

Whole plant Mg concentrations of western wheatgrass increased with advancing date throughout the growing season until September when levels began to decline (Fig. 2). In annual bromes, $\mathrm{Mg}$ concentrations decreased between June and July 1992 (Table 1). A soil $\times$ date interaction in whole plant $\mathrm{Mg}$ concentrations was observed for other cool-season grasses due to large differences in April 1992 concentrations between grasses from the 2 soils (Table 1 ). This was related to differences in growth patterns for the species comprising other cool-season grasses on the 2 soils. The dominant other cool-season grass on the silty clay soil was Sandberg's bluegrass which was actively growing in April and consisted of little dead material (16\%), while needle-and-thread was the dominant other cool-season grass growing on the loam soil and was $67 \%$ standing dead. Whole plant $\mathrm{Mg}$ concentrations did not vary over time for warmseason grasses $(0.12 \%)$, sedges $(0.18 \%)$, or forbs $(0.39 \%)$. 
Table 2. Least squares means \pm standard errors of mineral concentrations by tissue class for forage species groups.

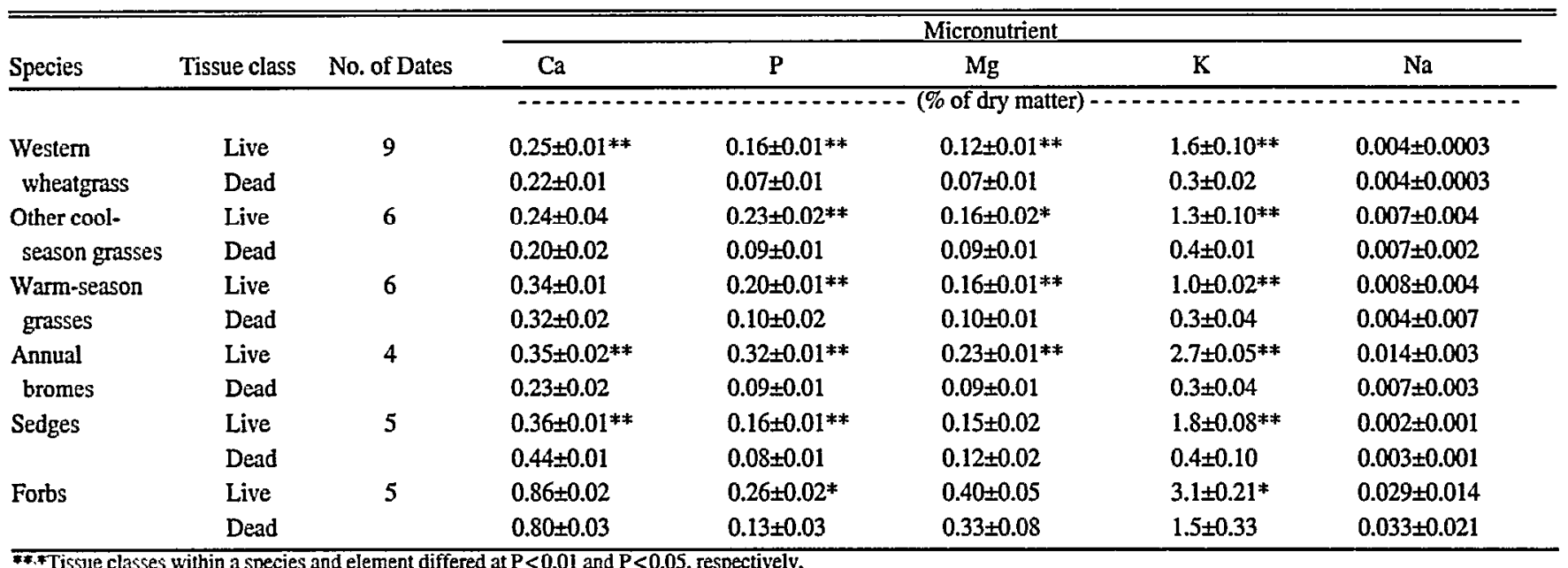

if.FTissue classes within a species and element differed at $P<0.01$ and $P<0.05$, respectively.

Magnesium concentrations of western wheatgrass $(0.11 \%)$ and annual bromes $(0.14 \%)$ collected from silty clay soil were greater when collected from loam soil ( 0.08 and $0.10 \%$, respectively). This soil effect was presumably related to the tendency toward greater $\mathrm{Mg}$ concentrations in the silty clay soil $(1,335 \pm 39 \mathrm{mg} / \mathrm{kg})$ than in the loam soil $(818 \pm 39 \mathrm{mg} / \mathrm{kg})$ according to April 1993 soil data. In addition, plant $\mathrm{Mg}$ uptake may have been limited by soil ion activity, with high $\mathrm{K}$ reducing $\mathrm{Mg}$ activity (Robbins and Mayland 1993). Soil K:Mg ratios were 0.2 for the silty clay and 0.3 for the loam soil.

Live and dead tissue differed in $\mathrm{Mg}$ content for western wheatgrass (Fig. 2), other cool-season grasses, warm-season grasses, and annual bromes (Table 2). Concentrations were also influenced by date in western wheatgrass (Fig. 2), forbs, and annual bromes, but this affect varied with tissue class (date $X$ tissue class interaction) for the latter 2 species. For forbs, live tissue contained greater amounts of $\mathrm{Mg}$ than dead tissue in July 1991, June 1992, and April 1993, but tissue classes did not differ in $\mathrm{Mg}$ on other dates. Live and dead tissue contained 0.42 and $0.27 \%$ in July $1991,0.50$ and $0.37 \%$ in June 1992, and 0.37 and $0.19 \%$ in April 1993, respectively. In annual bromes, live and dead tissue differed in $\mathrm{Mg}$ content on all dates. The tissue class $X$ date interaction was related to greater variation in live tissue (range 0.15 to $0.32 \%$ ) than in dead tissue (range 0.08 to $0.13 \%$ ).

\section{Potassium}

Average whole plant $\mathrm{K}$ concentrations of western wheatgrass were greater when growing on the silty clay $(1.14 \%)$ than loam soil $(0.92 \%)$. Whole plants of other cool-season grasses contained greater $\mathrm{K}$ concentrations when grown on the silty clay soil in April but less $\mathrm{K}$ when grown on this soil in July 1992. Potassium concentrations of warm-season grasses, annual bromes, and forbs varied over time (Table 1), while $\mathrm{K}$ concentrations in sedges $(1.5 \%)$ did not.

Potassium concentrations of whole plants were greatly influenced by live:dead ratios. For example, although $\mathrm{K}$ concentrations of live western wheatgrass were greatest in April 1992 (Fig. 2 ), live tissue comprised only $31 \%$ of the whole plant. Whole plant $\mathrm{K}$ was at its greatest level in June 1992, even though live tissue $\mathrm{K}$ had decreased from April levels, because the whole plant was now $64 \%$ live tissue.
Potassium in dead tissue was low on all dates, due to translocation and leaching of soluble $\mathrm{K}$ out of senesced material (Hinnant and Kothmann 1982). Potassium concentrations in live tissue were high (>2\%) in April for all species. Concentrations in live annual bromes in September of 1992 were also high (4.2\%) as a result of initiation of seedling growth following fall precipitation. Brome seedlings remained green throughout the winter and contributed to the live material collected in April 1993.

The suggested level of $\mathrm{K}$ for beef cattle diets is $0.65 \%$ of the diet dry matter. Therefore, $\mathrm{K}$ may be a limiting nutrient to livestock when they are consuming primarily mature forage. Karn and Clanton (1977) reported that supplementing $\mathrm{K}$ during the winter months on sandhills range in Nebraska prevented a depression in weight gains of weanling steer calves.

\section{Sodium}

All herbage Na concentrations were well below the recommended levels for livestock (0.08\%; NRC 1984) indicating the need for a continuous supply of salt to livestock grazing this type of vegetation. Western wheatgrass from the silty clay soil contained greater concentrations of $\mathrm{Na}(0.005 \%)$ than western wheatgrass grown on the loam soil $(0.003 \%)$. Whole plant concentrations of $\mathrm{Na}$ in other cool-season grasses grown on silty clay soil were higher than in plants grown on loam for August 1991 and April and August 1992 (Table 1). The Na content of other coolseason grasses grown on silty clay differed over dates, but plants grown on loam did not. No other whole plant species grouping varied in Na content over time or soil (data not shown).

Sodium concentrations of forage did not vary by tissue class for any species groupings (Table 2). For western wheatgrass there were date $X$ soil and date $X$ tissue class interactions (data not shown). Date also affected Na concentrations in annual bromes. Although concentrations differed by date, they did not follow any predictable pattern and were always low relative to animal requirements.

\section{Micronutrients \\ Zinc}

For whole plants, Zn concentrations varied by date in both warm-season grasses and sedges (Table 1). For warm-season grasses, this effect was due to an unusually high $\mathrm{Zn}$ concentration 
in July 1992. The date effect for sedges was related to low Zn concentrations in July 1991 and September 1992. Whole plant Zn concentrations of sedges were above the $30 \mathrm{ppm}$ level recommended for beef cattle (NRC 1984) in August 1991, but not at any other date (Table 1). Average whole plant $\mathrm{Zn}$ concentrations were $18 \mathrm{ppm}$ for western wheatgrass and other cool-season grasses, $20 \mathrm{ppm}$ for bromes and $31 \mathrm{ppm}$ for forbs. These results are similar to those of Munshower and Neuman (1978) who found that forage grasses grown in southeastern Montana averaged 17 ppm $\mathrm{Zn}$. Zinc concentrations did not vary by date in whole plants of other grass or forb species groupings, differing from the results of Murray et al. (1978), who found that $\mathrm{Zn}$ concentrations decreased throughout the growing season for downy brome, Sandberg's bluegrass, and needle-and-thread grown in southern Idaho.

Concentrations of $\mathrm{Zn}$ in live and dead tissue of all species except live warm-season grasses and forbs were below concentrations recommended for optimal animal health (Table 3). Date influenced $\mathrm{Zn}$ concentrations in live and dead tissue of all species groups except forbs (data not shown). However, a tissue class $X$ date interaction was observed for annual bromes and there was a tendency for this to occur for warm-season grasses. Although $\mathrm{Zn}$ varied, no real predictable pattern occurred during the growing season.

\section{Copper}

Whole plant $\mathrm{Cu}$ concentrations in annual bromes and sedges varied by date (Table 1), although in annual bromes concentrations only ranged between 2 and $4 \mathrm{ppm}$. Sedges showed a high concentration of $\mathrm{Cu}$ in August 1992. These results differ from those of Murray et al. (1978), who observed significant changes in $\mathrm{Cu}$ concentrations among dates for Sandberg's bluegrass and needle-and-thread but did not find consistent relationships for seasonal changes in $\mathrm{Cu}$ concentrations in downy brome. Copper concentrations in western wheatgrass, a major forage species, averaged $2 \mathrm{ppm}$ for both live and dead tissue. This is well below the suggested level of $8 \mathrm{ppm}$ for beef cattle (NRC 1984). Whole plant $\mathrm{Cu}$ averaged $7 \mathrm{ppm}$ for other cool-season grasses, $4 \mathrm{ppm}$ for warm-season grasses, and $13 \mathrm{ppm}$ for forbs.

Annual bromes were the only species with greater average $\mathrm{Cu}$ concentrations in live than dead tissue (Table 3). An exception was in June 1992, when both live and dead tissue contained 3 $\mathrm{ppm} \mathrm{Cu}$. Sedges and forbs contained over $10 \mathrm{ppm} \mathrm{Cu}$ on several dates and could contribute appreciably to the $\mathrm{Cu}$ intake of cattle. These 2 species also exhibited date $X$ tissue class interactions. Copper concentrations differed in the 2 tissue classes for forbs on all dates, but variation over time was greater for dead tissue (range $<1$ to $21 \mathrm{ppm}$ ) compared to live tissue (range 9 to 14 ppm). For sedges, $\mathrm{Cu}$ concentrations varied among tissue classes only in April and June 1992, with dead tissue containing greater amounts (22 and $11 \mathrm{ppm}$ ) of $\mathrm{Cu}$ than live tissue (5 and $3 \mathrm{ppm}$ ).

\section{Manganese}

Whole plant Mn concentrations of western wheatgrass were greater in April 1992 than at any other date (Table 1). Whole plant concentrations of $\mathrm{Mn}$ in annual bromes differed by date with April 1992 concentrations being greater than those in July and September 1991 and July, August, and September 1992. Manganese concentrations of other species were not affected by date and averaged $30 \mathrm{ppm}$ for other cool-season grasses, $41 \mathrm{ppm}$ for warm-season grasses, $53 \mathrm{ppm}$ for sedges, and $76 \mathrm{ppm}$ for forbs. Murray et al. (1978) were unable to develop equations relating date to $\mathrm{Mn}$ concentrations in downy brome and several cool-season grasses.

Western wheatgrass averaged $57 \mathrm{ppm} \mathrm{Mn}$ on the silty clay soil and only $37 \mathrm{ppm}$ on the loam soil. More Mn may have been present at the root-soil interface for the clay soil as this soil contained more $\mathrm{Mn}(24 \pm 2.2 \mathrm{ppm})$ in the top $10 \mathrm{~cm}$ than the loam soil $(10 \pm 1.0 \mathrm{ppm})$.

With the exception of other-cool season grasses (Table 3), average $\mathrm{Mn}$ concentrations of both live and dead tissue were greater than suggested levels for beef cattle (40 ppm; NRC 1984). Large variation in Mn concentrations within species, however, would make it difficult to accurately predict $\mathrm{Mn}$ concentrations in an animal's diet. Manganese content of annual bromes was not different between tissue classes except in April of 1992 and 1993

Table 3. Least squares means \pm standard errors of micromineral concentrations (dry matter basis) by tissue class for forage species/species groups in the Northern Great Plains.

\begin{tabular}{|c|c|c|c|c|c|c|}
\hline \multirow[b]{2}{*}{ Species } & \multirow[b]{2}{*}{ Tissue class } & \multirow[b]{2}{*}{ No. of Dates } & \multicolumn{4}{|c|}{ Micronutrient } \\
\hline & & & $\mathrm{Zn}$ & $\mathrm{Cu}$ & Mn & Mo \\
\hline & & & $\ldots \ldots$ & $\ldots$ & $\ldots . . .$. & . . . . . \\
\hline $\begin{array}{l}\text { Western } \\
\text { wheatgrass }\end{array}$ & Dead & & $15 \pm 0.7$ & $2 \pm 0.5$ & $49 \pm 0.9$ & $1 \pm 0.1$ \\
\hline \multirow{2}{*}{$\begin{array}{l}\text { Other cool- } \\
\text { season grasses }\end{array}$} & Live & $6^{2}$ & $12 \pm 7.9$ & $9 \pm 3.5$ & $21 \pm 8.8$ & $2 \pm 0.3$ \\
\hline & Dead & & $16 \pm 4.1$ & $4 \pm 5.5$ & $35 \pm 4.6$ & $1 \pm 0.2$ \\
\hline \multirow[t]{2}{*}{ Annual bromes } & Live & 4 & $24 \pm 0.9 * *$ & $6 \pm 0.2^{* *}$ & $97 \pm 6.3^{* *}$ & $1 \pm 0.3$ \\
\hline & Dead & & $17 \pm 0.8$ & $3 \pm 0.2$ & $66 \pm 7.5$ & $2 \pm 0.2$ \\
\hline \multirow[t]{2}{*}{ Sedges } & Live & 5 & $23 \pm 0.5$ & $8 \pm 1.0$ & $58 \pm 8.0$ & $\mathrm{na}^{3}$ \\
\hline & Dead & & $21 \pm 0.6$ & $12 \pm 1.3$ & $62 \pm 10.0$ & na \\
\hline Forbs & Live & $5^{2}$ & $30 \pm 2.9$ & $12 \pm 2.4$ & $80 \pm 5.1$ & na \\
\hline
\end{tabular}

Means for $\mathrm{Cu}$ include 7 dates.

Means for $\mathrm{Cu}$ include 4 dates.

* Tissue classes within a species and element differed $(\mathrm{P}<0.01)$.

${ }^{3}$ Mo concentrations were below detectable levels for most samples. 
when live tissue contained 1.7 and 2.2 times as much $\mathrm{Mn}$ as dead tissue which contained $70 \mathrm{ppm} \mathrm{Mn}$ in April 1992 and 54 ppm Mn in April 1993.

\section{Molybdenum}

Molybdenum was often below detectable concentrations $(<1$ ppm), limiting the number of values available for analysis. Soil Mo averaged $0.2 \mathrm{ppm}$. Date affected Mo concentrations in the 2 tissue classes of western wheatgrass and annual bromes, resulting in date effects on whole plant concentrations in western wheatgrass, sedges, and annual bromes and a tendency for date to affect Mo concentrations in warm-season grasses (data not shown). However, plant Mo content ranged only from 1 to $2 \mathrm{ppm}$.

\section{Conclusions}

Nutrients most likely to be found in quantities less than that recommended for optimal animal production were $\mathrm{P}, \mathrm{K}, \mathrm{Na}, \mathrm{Zn}$, and $\mathrm{Cu}$. From the results of this study, we conclude that tissue class plays a major role in influencing whole plant nutrient content for all macronutrients except $\mathrm{Na}$. Availability of different tissue classes may be used to assist in determining the mineral levels in cattle diets, especially with respect to $P$ and $K$.

The soil type on which forage grew affected concentrations of several nutrients. However, some of these effects were related to the effect of soil type on live:dead ratios. For example, differences among soils in $\mathrm{P}, \mathrm{Mg}, \mathrm{K}$, and $\mathrm{Na}$ concentrations in whole plants of other cool-season grasses over time may have been due to a large difference between the 2 soils on different dates in the proportions of live and dead tissue comprising whole plant samples.

\section{Literature Cited}

Adams, D.C. and R.E. Short. 1988. The role of animal nutrition on productivity in a range environment, p. 37-43 In: R.S. White and R.E. Short (eds.) Achieving efficient use of rangeland resources, Fort Keogh Research Symposium, Miles City, Mont.

Fleming, G.A. 1973. Mineral composition of herbage, p. 529-566. In: G.W. Butler and R.W. Bailey (eds.). Chemistry and biochemistry of herbage. Academic Press, New York, N.Y.

Greene, L.W., W.E. Pinchak, and R.K. Heitschmidt. 1987. Seasonal dynamics of minerals of forages at the Texas Experimental Ranch. J. Range Manage. 40:502-506.

Grings, E.E. 1979. Nutrient trends in diets of cattle grazing northeastern Colorado sandhills vegetation. M.S. Thesis. Colorado State University, Ft. Collins, Colo.

Karn, J.F. 1992. Ad libitum phosphorus supplementation of range cows in the Northern Great Plains. J. Prod. Agr. 5:409-413.

Karn, J.F. and D.C. Clanton. 1977. Potassium in range supplements. J. Anim. Sci. 45:1426-1434.

Karn, J.F. and L. Hofmann. 1990. Comparison of the copper and molybdenum status of yearling steers grazing reclaimed mined-land and native range. J. Range Manage. 43:69-72.

Hinnant, R.T. and M.M. Kothmann. 1982. Potassium content of three grass species during winter. J. Range Manage. 35:211-213.

Marsh, H., K.F. Swingle, R.R. Woodward, G.F. Payne, E.E. Frahm, L.H. Johnson, and J.C. Hide. 1959. Nutrition of cattle on an eastern Montana range as related to weather, soil and forage. Mont. Agr. Exp. Sta. Bull. 549. Bozeman, Mont.

Munshower, F.F. and D.R. Neuman. 1978. Elemental concentrations in native range grasses from the Northern Great Plains of Montana. J. Range Manage. 31:145-148.
Murray, R.B., H.F. Mayland, and P.J. VanSoest. 1978. Growth and nutritional value to cattle of grasses on cheatgrass range in southern Idaho. USDA For. Serv. Res. Paper INT-199. Intermountain Forest and Range Experiment Station. Ogden, Ut.

NOAA. 1992. Climatic data annual summary. Montana:95(13).

NRC. 1984. Nutrient requirements of beef cattle. 6th Ed. Nat. Acad. Sci., Washington, D.C.

Pinchak, W.E., L.W. Greene, and R.K. Heitschmidt. 1989. Mineral dynamics in beef cattle diets from a southern mixed-grass prairie. J. Range Manage. 42:431-433.

Rauzi, F., L.I. Painter, and A.K. Dobrenz. 1969. Mineral and protein contents of blue grama and western wheatgrass. J. Range Manage. 22:47-49.

Robbins, C.W. and H.F. Mayland. 1993. Calcium, magnesium, and potassium uptake by crested wheatgrass grown on calcareous soils. Commun. Soil Sci. Plant Anal. 24:915-926.

SAS. 1985. User's Guide: Statistics, Version 5 Edition. SAS Inst. Inc., Cary, N.C.

SCS. 1983. Technical guide, Section II-E-8. 10-14" Precipitation zone. Eastern Sedimentary Plains. Montana.

Sirois, P.K., M.J. Reuter, C.M. Laughlin, P.J. Lockwood. 1994. A method for determining macro and micro elements in forages and feeds by inductively coupled plasma atomic emission spectrometry. The Spectroscopist 3:6-9. 